\title{
RONDOM DIE FIGUUR VAN DS. DIRK VAN DER HOFFi)
}

\author{
A. D. PONT
}

Inleidende Opmerkings.

Vir die Teologiese Studentevereniging Van der Hoff en vir die erelede van dié vereniging is die jaar 1974 'n besondere gedenkjaar omdat dit die vyftigste bestaansjaar van die vereniging is. Gestig onder die leiding van die onvergeetlike professore J. H. J. A. Greyvenstein en S. P. Engelbrecht, het dié vereniging van teologiese studente homself in 1924 getooi met die naam van die baanbrekerpredikant van die Oorvaalse gebied ds. Dirk van der Hoff. Deur op dié manier ds. Van der Hoff en sy gedagtenis te eer, het die vereniging homself ook verbind met die figuur van ds. Van der Hoff; homself verbind met dié dinge waarvan ds. Van der Hoff die simbool is en geword het. Die figuur, die werk, die betekenis van ds. Van der Hoff word voortdurend deur hierdie vereniging beklemtoon en na vore gebring en so is dit ook deur dié vereniging verstaan. 'n Teken daarvan is dat reeds in 1928, in opdrag van hierdie vereniging. 'n brosjure verskyn het: Ds. Dirk van der Hoff. Die eerste predikant van Transvaal. Dit was in hoofsaak die werk van ds. Joh. Dreyer en met die medewerking van die destydse studente J. J. Prinsloo en P. W. Venter. Met hierdie publikasie het dié studentevereniging ook sy naam verantwoord. Merkwaardig genoeg is dit tot vandag toe die enigste selfstandige publikasie oor die lewe en werk van ds. Van der Hoff. Verskillende groter en kleiner artikels het met verloop van tyd wel verskyn naas die aandag wat aan sy persoon en werk gegee is in groter geskiedeniswerke ${ }^{2}$ ).

Wanneer vandag weer aandag gegee word aan die figuur en betekenis van ds. Van der Hoff en die reeds gepubliseerde materiaal word in oënskou geneem, dan is dit gou duidelik dat daar onder die historici en kerkhistorici géén eenstemmigheid is in die waardering van die lewe en werk van ds. Van der Hoff nie.

As die saak gestel word dat die Teologiese Studentevereniging Van der Hoff homself op 'n besondere manier verbind het aan dié dinge waarvan ds. Van der Hoff die simbool is, dan is, gesien die uiteenlopende waarderings, vanselfsprekend die volgende vraag: Waarvan is ds. Van der Hoff die simbool?

1) Referaat gehou by die Predikantevergadering, 26 Maart 1974.

2) $\mathrm{Vgl}$. in hierdie verband die verkorte litteratuurlys soos weergegee by $A$. D. Pont, Van der Hoff, Dirk, artikel in W. J. de Kock en D. W. Krüger. (red.) Suid-Afrikaanse Biografiese Woordeboek, Kaapstad 1972, DI. II, bls. 792 vgg. 
Daarop word, soos reeds aangedui, skerp verskillend geantwoord. Aan die een kant is daar die kerkhistorikus C. Spoelstra ${ }^{3}$ ) en die skool van historici wat sý gebruik van die bronne en sy interpretasie van die kerklike geskiedenis navolg. Aan die ander kant is daar die werk van die, aan ons so bekende, kerkhistorikus prof. S. P. Engelbrecht wat met die gebruikmaking van uitgebreider bronnemateriaal ' $n$ totaal ander beeld van die geskiedenis as Spoelstra en sy skool teken. Enigiemand wat enigermate tuis is in die SuidAfrikaanse kerkgeskiedskrywing merk dadelik dat ds. Van der Hoff in die kringe van die Spoelstraskool, op sy sagste gesê, 'n „omstrede figuur" is. Nou is dit mos so dat 'n ,omstrede figuur" altyd so ' $n$ persoon is wie se standpunt en houding nie aanvaarbaar of verteerbaar geag word deur die meerderheid van die dag nie.

As ds. Dirk van der Hoff, sy persoon, sy standpunt en wat hy verteenwoordig in 1974 nog steeds nie aanvaarbaar is nie ${ }^{4}$ ) dan is dit terselfdertyd óók duidelik dat ds. Van der Hoff, as navolgenswaardige en belangrike historiese figuur, in 1924 nog baie minder aanvaarbaar was. Tóg het ons Teologiese Studentevereniging by sy stigting geoordeel dat hy ondanks alles, vereenselwig wil wees met ds. Van der Hoff, dat die naam Van der Hoff sal weergee waaraan en waarvoor hierdie vereniging diensbaar wil wees.

Vandaar die vraag: wat sal dít wees? Waarom juis die naam Van der Hoff? Net omdat hy die eerste, voltydse, inwonende predikant in Transvaal was? Of is dit omdat hy die eerste predikantvoorsitter van die eerste sinodale vergadering in die Oorvaalse was? Of is dit omdat hy ' $n$ groot en toegewyde vaderlander was, ' $n$ patriot voordat die nasionale gevoel in Transvaal werklik tot ontwaking gekom het? Of is dit omdat ds. Van der Hoff ' $n$ baanbrekersrol in die kerklike, staatkundige, onderwys en kulturele lewe gespeel het in 'n grotendeels ongeordende Voortrekkergemeenskap, die blanke gemeenskap wat hier in die onbewoonde Oorvaalse ingetrek het en hier ' $n$ nasionale tuiste gevind het?

Om op al hierdie vrae ' $n$ afdoende antwoord te gee, is nie so eenvoudig nie omdat ondanks alles wat oor en rondom die figuur van ds. Dirk van der Hoff geskrywe is, daar nog steeds nie ' $n$ wetenskaplike verantwoorde biografie van hierdie interessante kerklike leiersfiguur bestaan nie. Dit het seker, om dit maar terloops

3) C. Spoelstra, Het Kerkelijk en Godsdienstig Leven der Boeren na den Grooten Trek, Kampen 1915. Dié werk se volledigheid en betroubaarheid is skerp aangeval deur S. P. Engelbrecht, Een Histories-Krities Onderzoek Histories Krities Onderzocht, artikel in Stemmen voor Waarheid en Vrede. 1917.

4) Vgl. in hierdie verband P. B. van der Watt, Die Loedolff-saak en die Nederduitse Gereformeerde Kerk 1862-1962, Kaapstad 1973, bls. 68 vgg. Dit moet bygesê word dat $V$ an der Watt se rustige en beredeneerde stellings en verantwoorde betoogtrant baie ver verwyder is van die byna-histerie van C. Spoelstra en baie van sy navolgers. 
te noem, tyd geword dat die Teologiese Studentevereniging andermaal dit oorweeg om 'n biografie van ds. Van der Hoff te laat skrywe. Afgesien daarvan dat die publikasie van 1928 nie meer vryelik beskikbaar is nie, is dit ook verouderd en beantwoord dit nie meer die vrae wat in 1974 rondom die figuur van ds. Van der Hoff bestaan nie.

By die gebrek aan so 'n volledige biografie is dit moeilik om afdoende te antwoord op die vraag: wie was ds. Van der Hoff? wat het hy verteenwoordig? Tog kan daar wel 'n paar opmerkings gemaak word wat kan aantoon dat ons Teologiese Studentevereniging nie sonder rede in 1924 homself met die naam van ds. Dirk van der Hoff getooi het nie.

Biografiese gegewens en 'n vlugtige bespreking daarvan.

Oor die biografiese gegewens van ds. Van der Hoff bestaan daar nie te veel onsekerheid nie. Die probleme ontstaan wanneer daardie gebeurtenisse geinterpreteer word. In ieder geval weet ons dat ds. Van der Hoff die tweede seun was van 'n Dordtse winkelier. Pieter van der Hoff en sy vrou Jacoba Botbijl. Die Van der Hoffgeslag wat uit Zevenbergen stam, was 'n gewone, stewige Nederlandse familie en as eerste uit hierdie familie het Dirk van der Hoff die predikantstudie aangepak.") $\mathrm{Na}$ voltooiing van sy teologiese studie aan die Leidse Universiteit waar hy onder die professore J. H. van der Palm, Joh. Clarisse, J. Voorst, W. A. van Hengel, en N. C. Kist studeer het en toegelaat is tot die evangeliebediening het hy tevergeefs op ' $n$ beroep in Nederland gewag.

In Mei 1854 is hy met die Dordtse meisie Anna Maria van Otterloo getroud en uit dié huwelik is drie kinders in Suid-Afrika gebore waarvan die twee seuns hom oorleef het. Nadat Van der Hoff op verskillende maniere sy tyd verwyl het en sy brood in Nederland verdien het, word hy deur bemiddeling van prof. W. Moll, die Amsterdamse teologieprofessor, in aanraking gebring met prof. U. G. Lauts wat vanweë sy besondere belangstelling in die Afrikaner, kontak met die Voortrekkers gehad het.

Deur prof. Lauts se toedoen is ds. Van der Hoff in Nederland georden deur die Commissie tot de zaken der Protestantsche Kerken in Neerlandsche Oost en West-Indiën ,.voor den evangeliedienst bij de Kaapsche boeren". In November 1852 kom ds. Van der Hoff in Kaapstad aan, word gelegitimeer by die actuarius synodi van die Kaapse Kerk en kom dan uiteindelik, nadat hy 'n beroepsbrief uit Transvaal ontvang het, in Mei 1853 in Potchefstroom aan.

i) S. P. Engelbrecht, Ds. Dirk van der Hoff en die Voortrekker-ideaal, artikel in Hervormde Teologiese Studies, Pretoria 1952, Jrg. 9, bls. 131. 
Dit klink alles ewe goed en aanvaarbaar. Maar so eenvoudig is dit nie. Afgesien van die feit dat hy in Dordrecht gebore is, daar grootgeword en in die huwelik getree het, is feitlik elke gebeurtenis in sy lewe daarna deur die historici van die Spoelstra-skool tot d3. Van der Hoff se nadeel uitgelê en verklaar.

Sy teologiese studie aan die Leidse Universiteit, so word onder andere deur G. D. Scholtz gestel, is die waarborg daarvoor dat hy die destydse liberale teologiese rigting toegedaan was. ${ }^{\circ}$ ) Dáárom sou hy dan ook nie 'n beroep in Nederland gekry het nie hoewel daar destyds 'n oorskot van predikante was. Skynbaar het die sogenaamde ortodokse predikante en proponente in Nederland méér beroepe gekry as wat hulle kon hanteer hoewel daar geen historiese bewyse of statistieke daarvoor aangevoer word nie. Die konklusie is dan ook al getrek deur W. H. Savornin Lohman dat die feit dat ds. Van der Hoff nie 'n beroep kon kry nie, net één betekenis het en dit is dat hy „voor zijn geestelijk werk ongeschikt (was), zoals uit zijn latere geschiedenis allerduidelikst gebleken is". ${ }^{\top}$ )

Van der Hoff se werkkringe in Nederland terwyl hy op 'n beroep gewag het, was ook nie bo verdenking nie en J. A. Smellekamp se stelling dat hy, in die tyd wat hy in Nederland op 'n beroep gewag het, 'n toneelspeler was, word tot vandag toe herhaal en beklemtoon. ${ }^{8}$ ) Daarby word die stellings ook gemaak dat ds. Van der Hoff se proponentseksamen nie in orde was nie; dat hy nooit behoorlik georden is in Nederland nie; dat hy georden is deur ' $n$ kommissie wat geen kerklike bevoegdhede gehad het nie; dat hy na Suid-Afrika gestuur is deur prof. Lauts wat bloot as 'n bevriende indiwidu opgetree het en géén reg gehad het om in die naam van die Volksraad van die Oorvaalse te handel nie èn dat die Nederlandse Hervormde Kerk geen verbintenisse hoegenaamd met ds. Van der Hoff of sy gaan na Transvaal gehad het nie. ${ }^{9}$ ) Met hierdie stellings word hoofsaaklik die standpunt van Spoelstra gevolg wat, ondanks die feit dat hy op bepaalde punte getuienis publiseer wat sy stellings weerspreek, tóg byvoorbeeld, daarin volhard dat ds. Van der Hoff nooit behoorlik in Nederland georden is nie. ${ }^{10}$ )

6) G. D. Scholtz, Die Geskiedenis van die Nederduitse Hervormde of Gereformeerde Kerk 1842-1885, Kaapstad-Pretoria 1956, bls. 79.

i) J. du Plessis. De Gereformeerde Kerk in wording en werking, Paarl 1925, bls. 2 en ook 30 .

Hierdie siening is die eerste maal gelug deur die nogal onbeskaafde ds. Dirk van Velden van Winburg wat op 12 Des. 1853 aan B. J. Badenhorst skrywe: .... de onregtzinnigen, die vijanden der zuivere waarheid worden geschuwd en blijven zonder beroep." Vgl. N. H. Kerkargief, SPE-Versameling, VII/1.

8) O.a. by J. du Plessis, a.w., b/s. 2

9) B. J. Odendaal, Die Kerklike Betrekkinge tussen Suid-Afrika en Nederland, 1652-1952, Franeker 1957, bls. 111-112.

1v) Vgl. C. Spoelstra, a.w., bls. 162 en ook 144 asook J. du Plessis, a.w., bls. 4. 
Op dieselfde manier is prof. Lauts en sy optrede onaanvaarbaar vir die historici van die Spoelstraskool en word hy en ds. Van der Hoff geskilder as die bose samesweerders wat daarin slaag om 'n kerklike skeuring in Transvaal te bewerkstellig met die "stigting" van die Ned. Hervormde Kerk. ${ }^{11}$ ) Selfs Van der Hoff se weiering op pad na Transvaal, om die beroep van die groep nedersetters te New Germany in Natal te oorweeg en om tog na Transvaal te gaan, word tot sy nadeel uitgelê. ${ }^{12}$ )

Terwyl die voorgeskiedenis van ds. Van der Hoff se werksaamhede in Transvaal so behandel word, kan ook begryp word dat sy werksaamhede en optrede in die jare 1853-1859 nog minder waardering van die Spoelstraskool ontvang. Ondanks historiese materiaal wat die teendeel bewys, word nog steeds in C. Spoelstra se spoor by voorkeur gepraat en geskryf van Van der Hoff schismaticus. ${ }^{13}$ ) 'n Ligtere sy in dié volskaalse aanval word verskaf deur die feit dat daar nog geen eenstemmigheid in daardie kringe bestaan oor die vraag wanneer ds. Van der Hoff toe presies die ,kerkskeuring" voltrek het nie. Die populêrste datum, so wil dit voorkom, is 1853 en daarvoor kies, om maar 'n paar te noem, C. Spoelstra, prof. J. du Plessis, B. J. Odendaal en G. D. Scholtz. ${ }^{14}$ ) Almal word egter weerspreek deur P. B. van der Watt wat meen dat die „afskeiding" eers in 1861 'n voldonge feit geword het en dat eers in daardie jaar "'n nuwe kerk" in Transvaal ontstaan het. ${ }^{15}$ ) Ander moontlikhede wat genoem word is die jaar 1858 terwyl die jaar 1854 óók sy voorstanders het. In ieder geval in daardie kringe word ds. Van der Hoff voorgestel as 'n skeurmaker, as ' $n$ vervalser van die notules van die Algemene Kerkvergadering, as 'n liberalis en 'n volkome oneerbare figuur.

Die byvoeglike naamwoorde waarmee ds. Van der Hoff en sy werksaamhede beskrywe word, word nog onguurder wanneer gehandel word oor ds. Van der Hoff se verhouding tot die gemeente Lydenburg, Oos-Transvaal en sy botsing met J. A. Smellekamp wat gelei het tot die verbanning van Smellekamp uit Transvaal. Die noot hiér is ingesit deur die Nederlandse reggeleerde $C$. Hiddingh wat in 1856 'n reis na Suid-Afrika gemaak het en onder andere 'n rapport oor sy bevindinge aan die Amsterdamse Kommissie gemaak het. Om 'n indruk te kry van die kwaliteit van die aanvalle, kan net verwys word na Hiddingh se rapport wat onder andere stel: ${ }^{16}$ )

11) O.a. G. D. Scholtz, a.w., bls. 77-79.

12 B. J. Odendaal, a.w., bls. 111.

13) C. Spoelstra, a.w., bls. 147.

11) Vgl. J. du Plessis, a.w., bls. 9 vg., C. Spoelstra, a.w., bls. 149, B. J. Odendaal, a.w., bls. 115, G. D. Scholtz, a.w., bls. $83 \mathrm{vg}$.

15) P. B. van der Watt, a.w., bls. 72.

16) C. Spoelstra, a.w., bls. 179. Vgl. in hierdie verband ook S. P. Engelbrecht, Geskiedenis van die Nederduitsch Hervormde Kerk van Afrika, Pretoria 1953, bls. $117 \mathrm{vg}$. 
„Zijne gedragingen, zoo ten opzigte van de Kerk, als ten aanzien der kerkelijke aangelegenheden, hebben verre het meerendeel der gemeente van hem verwijderd. Hoogmoedig en strevende naar eene onbeperkte heerschappij, behandelde hij de menschen norsch en terugstootend hij ging hun slecht voor in daad en wandel; in zijn eigen huis was de vrede en eensgezindheid dikwerf gestoord op eene rumoermakende wijze naar buiten; hij zocht te gemeenteleden niet op, welke zijnen raad en zijne vertroosting noodig hadden, hoezeer zij die ook wenschten; zijne dienst bepaalde zich tot het eenmaal prediken des Zondags, het toedienen der Heilige Sacramenten en het aannemen van ledematen ..."

As, in die verbygaan, net in ag geneem word dat Hiddingh wèl uitvoerig besoek afgelê het by een van ds. Van der Hoff se venygste vyande, J. A. Smellekamp, maar nie by óf ds. Van der Hoff self of Kommandant-Generaal M. W. Pretorius nie dan is dit tog merkwaardig dat historici wat andersins wèl in staat is om die waarde van historiese bronne te skat, hierdie uitlatings as die onvervalste waarheid erken.

Net so merkwaardig is dit dat ds. Van der Hoff deur die historici van die Spoelstraskool byna man-alleen verantwoordelik gehou word vir die afskeiding en die stigting van die Republiek Lydenburg; dat hý beskou word as die hoofoorsaak van die afskeiding van ds. Dirk Postma èn dat hy vanaf 1853 niks anders sou gedoen het as om die Transvaalse volk te verdeel en stelselmatig na die afgrond te rig met sy preke, wat skynbaar die essensie van die liberalisme was nie èn dat hy deur sy uitspattige, wanordelike gedrag en verregaande heerssug die kerklike gemeenskap waarin hy gewerk het feitlik volkome van die evangelie en die diens van God vervreem het. Géen kwaad het skynbaar in die Transvaal ontstaan of bestaan vanaf 1853 nie of, so word ewe gewigtig gestel, ds. Dirk van der Hoff is in laaste instansie die aanstigter, die drywer, die beplanner van dié onheil nie.

Die opvallende van hierdie soort geskiedskrywing is dat dit nié rekening hou met al die beskikbare historiese materiaal nie en verder dat dit die optrede, werk en handelwyse van ds. Dirk van der Hoff grotendeels verklaar vanuit ' $n$ animus wat teen sy persoon skyn te bestaan èn vanuit ' $n$ animus wat daar teen die Ned. Hervormde Kerk as die "skeurkerk" skyn te bestaan. Dit word verder veral merkwaardig as gesien word dat hierdie soort geskiedskrywing nié toe- 
gepas word op 'n figuur soos ds. Frans Lion Cachet nie oor wie se leer, lewe en optrede nogal die een en ander op te merk is. ${ }^{1 i}$ )

Die historici van die Spoelstra-skool konsentreer die aanval op die persoon van ds. Van der Hoff gewoonlik op die beginjare van sy werk in Transvaal. Dit hang waarskynlik saam met die hele poging om ten alle koste aan te toon dat die Ned. Hervormde Kerk 'n „,skeurkerk" sou wees. Om dit te kan doen, word gewoonlik ook die naamkwessie na vore gebring en word getrag om so aan te toon dat die Ned. Hervormde Kerk nié die enigste en logiese voortsetting van die onafhanklike Voortrekkerkerk was nie.

Dit is interessant om vas te stel dat die hele argument rondom die naam van die Kerk nog steeds nie in staat was om finale uitsluitsel te gee of die Ned. Hervormde Kerk 'n "skeurkerk" is of nie. Die kerkregtelike argument wat hier veel meer ter sake is, is tot dusver nog nie volledig uitgewerk nie maar dit sal veel meer lig op hierdie aangeleentheid werp. ${ }^{\text {s. }}$ )

In ieder geval, die beperking van die aanvalle op ds. Van der Hoff tot die eerste jare van sy ampsbediening in Transvaal, beteken dat die figuur van ds. Van der Hoff by die historici van die Spoelstraskool in 'n nogal vertekende vorm na vore kom. Dit, so moet mens aanneem, is seker ook die bedoeling. Maar daar kan tog heelwat meer oor ds. Van der Hoff gesê word indien 'n enigsins objektiewe beeld van hierdie baanbrekerpredikant geteken wil word.

Dit sou te ver voer en dit is bowendien nogal ' $n$ vermoeiende saak om al die argumente van die Spoelstraskool hiér te weerlê. Buitendien sal dit, in hierdie kring, wel duidelik wees dat daar ook ander materiaal rondom die lewe en werk van ds. Van der Hoff bestaan as net dié wat deur die Spoelstraskool na vore gebring word. Daardie ander materiaal, wat gedeeltelik deur prof. S. P. Engelbrecht verwerk is, laat wel 'n ander lig op ds. Van der Hoff val.

Met die opsomming van sommige van die argumente van die historici van die Spoelstraskool waarmee ds. Van der Hoff gewoonlik "afgemaak" word, word net aangetoon in watter merkwaardige lig die eerste blanke bewoners in die Oorvaalse en hulle predikant soms gestel word. Immers as ds. Van der Hoff as predikant 'n volkome eerlose mislukking was, dan beteken dit tog dat die kerklike

1:) Biografiese gegewens word o.a. verstrek deur S. P. Engelbrecht, Ds. Frans Lion Cachet, artikel in Hervormde Teologiese Studies, Pretoria 1953, Jrg. 9 bls. 181-123.

Vgl. ook S. P. Engelbrecht, Nogmaals Dr. G. D. Scholtz ens., artikel in Hervormde Teologiese Studies, Pretoria 1958, Jrg. 13, bls. 156.

18) A. D. Pont, Die Vestiging van die Ned. Hervormde Kerk in 1853, artikel in Hervormde Teologiese Studies, Pretoria s.j., Jrg. 20, bis. 149 vgg.

Sien ook P. B. van der Watt, a.w., bls. $47 \mathrm{vg}$. 
gemeenskap wat hom as predikant en geestelike leier gehandhaaf en geëer het, min of meer van dieselfde kwaliteit was. Dan is hulle nié die stoere pioniersfigure wat met stryd en swaarkry vir die Afrikaner 'n nuwe, vrye, nasionale tuiste in die Oorvaalse geskep het nie. Dan was hulle eintlik maar net ' $n$ klomp half-beskaafde fortuinsoekers waaroor ons ons vandag moet skaam en hoef ons ons ook nie juis te steur aan die stoflike en geestelike erfenis wat hulle ons nagelaat het nie.

Dit wil my voorkom dat die historici van die Spoelstraskool in hulle ywer om ds. Van der Hoff en die Ned. Hervormde Kerk by te kom, in hulle aanvaarding van elke skinderstorie wat deur die vyande van die ou Voortrekkers in omloop gebring is, besig is om 'n skewe beeld van die vroeë bewoners van die Oorvaalse te teken, van daardie mense wat die land met hulle swaarkry en dikwels hulle bloed skoon- en bewoonbaar gemaak het en wat die werklike besitters van al die grondgebied noord van die Vaalrivier was.

Dit is, soos reeds gestel, nie nodig om vandag alles wat teen ds. Van der Hoff al gesê of geskrywe is, te weerlê nie of om hiér 'n volledige beeld van sy lewe en werk te gee nie. Maar dit kan tog waarde hê om, al is dit kortliks net aan te dui op watter vlakke, naas die kerklike, ds. Van der Hoff 'n rol van besondere verdienste in die vroeë Transvaalse gemeenskap gespeel het.

Dan kan ten eerste gesê word dat dit tog onwaarskynlik is dat 'n oneerlike heerssugtige, wanordelike, drankverslaafde ds. Van der Hoff, soos die Spoelstraskool hom so graag teken, inderdaad só leiding sou kon gegee het in die Transvaalse gemeenskap soos ds. Van der Hoff wèl gedoen het. Dat ds. Van der Hoff, soos enige ander menslike wese, foute gemaak het, moet aanvaar word. Wat die kwaliteit van dié foute was, sal omskrywe moet word, maar dit was seker nooit van só 'n aard dat dit onberekenbare skade aangerig het nie. Hoewel ds. Van der Hoff wèl 'n bydrae gelewer het tot die afskeiding van Lydenburg op kerklike en staatkundige vlak ${ }^{19}$ ) is dit tog ongebalanseerd om hom, op grond dáárvan, tot totaalonverantwoordelik uit te maak. Dit klop dan in ieder geval nié met die oordeel van die Gereformeerde kerkhistorikus, prof. dr. B. Spoelstra, oor ds. Van der Hoff en sy optrede tydens die Algemene Kerkvergadering van 1859 waar die ,psalmsingers" hulle aan die gemeenskap van die Kerk onttrek het. ${ }^{20}$ )

Dit is verder nog 'n oop vraag of die Oos-Transvaalse Lydenburgers nie buitendien, sonder die prikkel wat verskaf is deur die

19) Vgl. A. D. Pont, Van der Hoff, Dirk, bls. 794.

2u) Vgl. B. Spoelstra, Die "Doppers" in Suid-Afrika, 1760-1899, Kaapstad 1963, bls. $137-140$. 
botsing tussen J. A. Smellekamp en ds. Van der Hoff in 1854, hulle sou losgemaak het van die Wes-Transvaalse deel van die Voortrekkergemeenskap nie. Staatskundigkultureel-strategies was daar 'n groot gaping tussen die siening van dié twee groeperinge. Die onbetwisbare feit bly verder staan dat die ordening van die Voortrekkergemeenskap, nà die oprigting van die Republiek Lydenburg, met rasse skrede positief vooruitgegaan het. Die herinskakeling van Lydenburg wat staatkundig geen probleme opgelewer het nie het alleen kerklike probleme geskep danksy die figuur van ds. Frans Lion Cachet. Die kerklike verdeeldheid wat in die ou Zuid-Afrikaansche Republiek ingedra is met die hertoetrede van Lydenburg tot die Republiek het tog die feit beklemtoon dat Lydenburg ' $n$ ànder kultureel-staatkundige en kerklike visie gehad het as die WesTransvalers of die Pretoriusparty. Dit het later op die staatkundige gebied telkens na vore gekom.

In ieder geval, as ds. Van der Hoff se optrede in 1854 en sy botsing met J. A. Smellekamp as leiersfiguur van die Lydenburgers beoordeel word, dan moet dit in die lig van die bestaande spanning tussen die Wes- en Oos-Transvalers gesien word as dit gebalanseerd beoordeel wil word.

Dan moet rekening gehou word met die feit dat ds. Van der Hoff in bepaalde kringe in die ou Republiek nié gewild was nie omdat hy van die begin af op staatkundige vlak hom met die Pretoriusparty verbind het. Dié party het hoofsaaklik in die begin in Wes-Transvaal bestaan uit die volgelinge van Kommandant-Generaal A. W. J. Pretorius. Na sý dood het sy seun, die latere President $M$. W. Pretorius die leiding oorgeneem en na hom President Paul Kruger. Hierdie party is nog met 'n geleentheid deur ds. Frans Lion Cachet, in Het Volksblad, 18-10-1876, getipeer as .,known by insolence, stupidity, lethargy, ignorance of all affairs beyond their farms, hatred of European civilization, progress and of Englishmen and Kaffirs particularly". Dié beskrywing van die ruggraat van die Transvaalse bevolking is egter tiperend van die manier waarop die gewone, normale, Christen-Afrikaner wat gesteld is op die handhawing van sy eie identiteit en selfbeskikkingsreg deur die tyd heen tot vandag toe beskrywe word deur diegene wat hom wil kleinkry. Ds. Van der Hoff se staatkundig-kulturele-kerklike standpunt het later meegebring dat in die jare 1865 en 1866 uit Wakkerstroom se wêreld klagtes teen sy kerklike regsinnigheid gelê is. Klagtes wat in ieder geval nie deur die Kommissie van die Algemene Kerkvergadering, wat gesteld was op die handhawing van die leer van die Kerk, in ' $n$ baie ernstige lig beskou is nie. Om op grond daarvan en byvoorbeeld die opvattings van ds. J. P. Jooste van Potchefstroom, ds. Van der Hoff as ' $n$ verteenwoordiger van die liberale teologie te beskrywe, kan histories-wetenskaplik nié aanvaar word nie. 
Die probleem, by die beoordeling van ds. Van der Hoff se teologiese standpunt, is onder andere dat daar géén geskrewe preke van hom oorgebly het nie. Om alleen op grond van sy studie aan die Leidse universiteit ds. Van der Hoff tot liberaal te verklaar, is moeilik houdbaar. Om uit sy kerkordelike arbeid, dit wil sê die voorlopige Kerkwet van 1857 en die Kerkwet van 1862 af te lei dat hy liberaal was, sou beteken dat in die hele Ned. Gereformeerde Kerk van die negentiende eeu geen enkele ampsdraer of predikant was wat nie liberaal was nie want almal het die kerklike ordeninge van 1824 en 1842, waarop die Ned. Hervormde Kerkwette van 1857 en 1862 gebaseer was, sonder openbare protes aanvaar.

Heelwat hang natuurlik daarvan af wat presies onder die begrip liberaal verstaan word. In die dae van ds. Frans Lion Cachet, toe dié beskuldiging die eerste maal na vore gekom het, het die begrip nie veel meer om die lyf gehad as in skeldwoord wat die teenparty aandui nie. Alles en almal wat nié arminiaans-metodisties was nie en wat nie aanvaarbaar was vir die metodistiese, pro-Engelse party in die Kaapse Sinode nie, is uitgemaak vir liberaal en daarmee gebrandmerk as 'n uitgeworpene. Vir dié begrip liberaal kwalifiseer ds. Van der Hoff waarskynlik wèl aangesien hy geen arminiaanse metodis was nie. Dit is egter opvallend dat die historici die beskuldiging van liberaal ten opsigte van ds. Van der Hoff vryelik gebruik sonder om aan te dui wáár en wat dié liberalisme presies inhou.

Dit is egter duidelik dat ds. Van der Hoff in 1974, net soos gedurende sy lewe, in 'n slegte lig gestel moet word om sodoende die aanklag van "die sondige verskeurdheid" van die Afrikaanse kerke sorgvuldig aan die deur van die Ned. Hervormde Kerk te lê. Sodoende word die aandag dan ook afgetrek van die predikante van die Kaapse Kerk wat gedurende die negentiende eeu van die ywerigste bevorderaars was van die Britse imperiale politiek in Suid-Afrika. Hier kan gerus met sorgvuldigheid geluister word as S. P. Engelbrecht stel: „Die Kaapse Kerk was beslis teen die Groot Trek gekant, en sy belangstelling vir die Trekkers was alleen tot daardie dele beperk waar die Britse vlag hulle agterhaal het." $\left.{ }^{21}\right)$ Dáárdie faktor, wat normaalweg volkome negeer word deur die historici van die Spoelstraskool, het 'n baie belangriker rol gespeel in die gebeure van 1853 en 1865-1866 in die Oorvaalse as net die persoon en werk van ds. Dirk van der Hoff alleen. Die feit dat die Vryheidsoorlog van 1880-1881 en die oorlog om die goud van Transvaal in 1899-1902 'n diepgaande nasionale bekering in die

:1) S. P. Engelbrecht, Ds. Dirk van der Hoff, bls. 131. 
geledere van die Nederduitse Gereformeerde Kerke in Suid-Afrika teweeggebring het ten opsigte van die Engelse imperialisme wat die voortbestaan, identiteit en welsyn van die Afrikaner se Kerk en volk bedreig het, maak die geskiedenis van die dertiger tot die negentigerjare van die vorige eeu nog nie ongedaan nie. ${ }^{22}$ )

Een van die resultate van dié soort geskiedskrywing, soos dié van die Spoelstraskool, is dat ds. Van der Hoff se groot en verdienstelike bydrae tot die ordening en bestendiging van die Voortrekkergemeenskap in die jare 1853-1881 nie raakgesien of in berekening gebring word nie.

Hierdie werk wat hy langs sy gewone werksaamhede as predikante gedoen het, gee 'n baie interessante kykie op die persoon van ds. Van der Hoff èn die toonaard van sy werk hier in die Oorvaalse gebied.

Hier kan gedink word aan sy bydrae om die onderwys in die ou Republeik op ' $n$ gesonde voet te plaas èn die feit dat hy tot in. 1867 voorsitter van die Staatskommissie van Onderwys was.

Nie alleen so nie, maar juis deur sy volgehoue en toegewyde pastorale werksaamhede het ds. Van der Hoff in die vyftiger-, sestiger- en sewentigerjare, in die opbou van 'n stewige, kerklike gemeenskap ' $n$ konsoliderende rol gespeel in die Transvaalse ge-: meenskap wat nog geen sterk, onderlinge nasionale verbondenheid gehad het nie. ${ }^{23}$ ) Hoewel ds. Van der Hoff van die begin af verbonde was aan die Pretoriusparty het die op-en uitbou van die Ned. Hervormde Kerk tog meegehelp om 'n nasionale eenheidsband te skep. In 1857, om maar 'n voorbeeld te noem, het die Algemene Kerkvergadering tydens sy eerste sitting in Pretoria onder leiding van ds. Van der Hoff 'n skrywe gerig aan die President $M$. W. Pretorius en die Kommandante-generaal Steph. Schoeman en W. F: Joubert wat skerp teenoor mekaar gestaan het. Daarin is, onder andere, gestel: ${ }^{24}$ )

„Ofschoon het niet in onze roeping ligt en ook niet tot onze werkkring behoort, om ons enigzins in te laten met de politiek, zoo rekenen wij het toch onze plicht, om met $U$ over den tegenwoordigen toestand van zaken te

22) Interessantheidshatwe kan hier net vermeld word dat ds. H. S. Bosman in Pretoria begrawe le onder 'n grafsteen wat hom as Volksman huldiag. Dit neem egter nie weg dat hy in 1881 voor " $n$ Boerekrygshof in Heidel: berg tereggestaan het op in aanklag van landverraad. Hoewel hy vrygespreek is, mede deur die bemiddeling van ds. $N$. J. van Warmelo, was ds. H. S. Bosman en wat hy in die kerklik-staatkundige lewe verteenwoor: dig het één van die aanleidende oorsake waarom die Konsulentsgemeente van Pretoria in 1885 nié aan die Kerkvereniging deelgeneem het nie.

23) A. N. Pelzer, Wordingsjare, Kaapstad 1950, bls. 204.

24) S. P. Engelbrecht, Die Nederduitsch Hervormde Gemeente Pretoria, 1855: 1955. Pretoria 1955, bls. 18. 
spreken. Wij zien de ongelukkige verdeeldheid die er bestaat in de politieke aangelegenheden, en wij huiveren voor de gevolgen die daaruit zullen kunnen voortvloeien daarom verzoeken wij $U$, om onderling eene bijeenkomst te houden en zelf in persoon tegenwoordig te zijn, en tot die bijeenkomst uitnoodigen de verstandigste en godsdienstigste lieden, ten einde onder Gods zegen broederlijk met mekaar te vereenigen en den band van eenheid, vrede en liefde onder ons te herstellen...

De eenheid in onze geestelijke zaken mogen $U$ ten spoorslag strekken, om ook in het politieke diezelfde eensgezindheid te bevorderen."

Hoewel hierdie poging nié onmiddellik al die spanning tussen Potchefstroom en Zoutpansberg kon oplos nie, het dit seker daartoe bygedra dat Pretorius en Schoeman teen die helfte van 1857 tot ' $n$ voorlopige versoening gekom het. Eers na die „burgeroorlog" wat in 1864 geëindig het, het daar méér rus en vrede in die land gekom. Duidelik is dit wel dat die rol wat ds. Van der Hoff hier gespeel het om eensgesindheid te verkry, nié onderskat moet word nie.

uie vestiging van die Gereformeerde Kerk in 1859 in die ou Republiek het, vanweë die goeie verhouding tussen ds. Van der Hoff en ds. Potsma en die eenselwigheid van die staatkundig-kulturele strewe van die lidmate van die twee kerke, nie 'n addisionele verdelende faktor geword nie. Die afskeiding van ds. Frans Lion Cachet in die jare 1865-1866, wat eintlik geen groot skeuring in die Ned. Hervormde Kerk meegebring het nie, het wèl die afwykende kerklike opvatting en die aweregse staatkundig-politieke opvattinge saamgesnoer. As drukgroep was hierdie party, vanweë sy noue verbondenhede met die Suide en die Engelse imperialisme, staatkundig wel belangrik. Vir die uitbouing van die Voortrekkerideaal en die Afrikaner se nasionale opvattings en gevoelens het hierdie groep geen besondere bydrae gelewer nie. ${ }^{25}$ )

Dit kan gestel word dat tot op hierdie stadium daar nog nie gepoog is om ds. Van der Hoff èn die Ned. Hervormde Kerk se invloed op die staatkundig-politieke en kulturele vlak in die ou Republiek te evalueer nie. As daarmee rekening gehou word dat die latere Staatspresident Paul Kruger in die openbare lewe in hoofsaak die woordvoerder was van dié deel van die Transvaalse volk wat kerklik in die Ned. Hervormde en die Gereformeerde Kerke saamgesnoer was, dan word dit duidelik dat dit nodig is dat die rol van ds. Van der Hoff en die Ned. Hervormde Kerk in die worsteljare van

25) S. P. Engelbrecht, Thomas Francois Burgers, Pretoria 1933, bls. 242-243. 
die ou Republiek nagevors en beskryf moet word. ${ }^{26}$ ) Dan moet verder onthou word dat as ds. Van der Hoff in Mei 1878 sy 25-jarige ampsjubileum vier, hy dit doen te midde van 'n kerklike gemeenskap wat dan al uit 19500 siele bestaan en deur sewe predikante bedien word. Op daardie stadium was dit die oorgrote deel van die bevolking van die ou Republiek veral as in ag geneem word dat met die Presidentsverkiesing van 1883 daar nog nie vyfduisend stemgeregtigde burgers hulle stemme uitgebring het nie. As terselfdertyd die algemene agting en waardering waarmee ds. Van der Hoff in die Ned. Hervormde Kerk self bejeën is, in berekening gebring word, dan kan op dié manier die omvang van sy werkterrein en invloedsfeer gepeil word. Die stelling kan dus, selfs op hierdie stadium, met gerustheid gemaak word dat ds. Van der Hoff in die grotendeels ongeordende Voortrekkergemeenskap waarin hy in 1853 ingetree het, baanbrekers- en beskawingswerk van onskatbare waarde verrig het.

In hierdie selfde verband moet sy bydrae tot die totstandkoming van die eerste grondwet van die ou Zuid-Afrikaansche Republiek ook genoem word. Daardie eerste grondwet het maar bitter moeilik tot stand gekom vanweë die verskille wat tussen die verskillende leiersfigure en faksies in die Transvaal bestaan het en eers met die beëindiging van die ,burgeroorlog" van 1864 is die grondwet algemeen aanvaar.

Ds. Van der Hoff se aandeel tot die totstandkoming van die grondwet is nie gering nie en sy bydrae tot die simbole van die Republiek is om die Transvaalse vierkleur te ontwerp, daardie ,,roemoorlaaide vlag wat nooit oor die kop van 'n onderdrukte volk gewaai het nie." Dit is interessant om kennis te neem van ds. Van der Hoff se uitleg van die simboliek van die kleure van die nuwe landsvlag juis omdat daaruit ook iets afgelei kan word van sy patriotisme. Hy het in dié verband gestel: ${ }^{2 i}$ )

\section{„Het Rood in de Vlag.}

Zie daar de helder roode kleur boven aan. De kleur is de bloedskleur, maar het is juist de bloedkleur, die elke tegenstander, elken vijand toeroept: met onze bloed zullen wij onze vrijheid verdedigen; onze bloed offeren wij voor onze vrijheid op!

\section{.Het Wit.}

Ziet daar de reine witte kleur in het midden. De kleur is het zinnebeeld van reinheid en zuiverheid van bedoelingen. $\mathrm{Zij}$ roept den vijand toe: als wij strijden voor onze

a) A. N. Pelzer, a.w., bls. 200-201.

2i) The Transvaal Advocate and Commercial Advertiser, 23 Nov. 1873. 
vrijheid en ons bloed voor haar doen vioeijen dan hebben wij geen enkele onedele bedoeling; en als wij in dien strijd uw bloed doen vloeijen, dan zijn wij onschuldig aan dat vergoten bloed.

\section{Het Blaauw.}

Ziet op naar den hemel; naar dat blaauw des hemels, dat als een tentgordyn boven onze hoofden is uitgespannen. Dat hemelsblaauw is als het afschijnsel der Godheid die boven haar troont. En op die Godheid, zegt het blaauw in de vlag, stelt mijn volk zijn vertrouwen.

Heerlijke zinnebeelden. En nu sprak ik nog nie van het groen, waaraan die zinnebeeldige kleuren verbonden zijn en die haar nog heerlijker doen uitkomen. Het groen immers is de kleur der hoop en zegt dus als met duidelike woorden: wij hebben goede hoop, dat wij met Gods hulp, in reinheid en zuiverheid van bedoelingen onze vrijheid zullen handhaven en bidden God dat geen menschelijke macht ons die vrijheid ooit ontnemen zal."

Met die ontwerp van die vlag, net soos met sy bydrae tot die totstandkoming van die grondwet, was dit duidelik dat ds. Van der Hoff ' $n$ konsoliderende middelpunt gesoek het wat 'n samebindende faktor in die verspreide Boeregemeenskap van die Oorvaalse sou wees.

Dieselfde beweegrede het hom daartoe gebring om ook sy gewig in te gooi om 'n sentrale hoofstad in die Republiek te verkry. Hoewel Kommandant-Generaal M. W. Pretorius en die Volksraad in beginsel so besluit het, het daar van die uitvoering van die besluit nie veel gekom nie. Dit was ' $n$ verskynsel wat in die vroeë Republiek, wat geen ander uitvoerende gesag as die periodiek-vergaderende Volksraad gehad het nie, meermale voorgekom het. Dit was ds. Dirk Van der Hoff wat die stigting van Pretoria daadwerklik bevorder het deur allereers die gemeente Pretoria Philadelphia te stig en deur in 1855 kerkdienste te hou hier waar twee plase vir die oprigting van die hoofstad aangekoop is. Grotendeels vanweë ds. Van der Hoff se optrede het die Volksraad pók begin roer en is mettergaan begin om Pretoria as dorp en as hoofstad te ontwikkel. ${ }^{28}$ )

Ter wille van die eenwording en samewerking, wat so dikwels in die vroeë jare gehaper het, het ds. Van der Hoff ook telkens die Voortrekkerideaal, waaraan hyself met hart en siel verknog was, duidelik na vore gebring en gestel. Hocwel die eenheidsgevoel en

2s) S. P. Engelbrecht, Die N.H. Gemeente Pretoria, bls. 2-16. 
vaderlandsliefde van die burgers van die Transvaalse Republiek eers werklik tot ontwaking kom in die periode nà 1877, was dit alleen moontlik omdat die fondamente daarvoor reeds veel vroeër gelê is. Reeds in 1856 het ds. Dirk van der Hoff die vryheidsideaal van die Voortrekkers onder woorde probeer bring as hy in 'n gedig onder andere stel:"99)

"Zoo antwoord vrij en onbeschroomd:

'Wij werden door den Brit gehoond'

Want door zijn woest en dom geweld

Werd wit en zwart gelijk gesteld.

Gelijk gesteld? Neen, boven ons verheven

En d'onrechtvaardigheid ten hoogsten top gedreven!

Wie dat verdragen kon, wij konden 't niet verdra'gen,

maar wilden liever alles wagen, om onze vrijheid na te jagen."

En dan, verwysende na die pogings om die Tarnsvaalse Kerk weer ingesluit te kry in die Kaapse kerklike organisasie, stel hy:

„Maar neen, de vrijheid die door God ons is geschonken, Zij wordt nooit weer op nieuw in boei en dwang geklonker.

$Z_{i j}$ is 't geschenk van God, zij is betaald met bloed,

Zij blijv' Uw erfenis, Uw onvervreembaar goed."

Die bekende Vlaggelied wat ds. Van der Hoff gedig het as 'n soort eerste volkslied van die nuwe Republiek, het dieselfde vaderlandsliefde en vryheidsin geopenbaar. Hierdie vereenselwiging met die Voortrekkers en die ideale wat hulle gekoester het, juis sy pogings om mee te help om hierdie ideale in die ou Republiek te verwerklik het ds. Van der Hoff die vyand gemaak van omtrent elke metodistiese, pro-Engelse Kaapse predikant. Dieselfde patriotiese gedagtes wat sy gediggies weerspieël, word ook gevind in ds. Van der Hoff se brosjure van 1857 Eene Stem uit de Kaapstad. . . weerkonken in Mooirivier waar ds. Van der Hoff duidelik stelling inneem teen die kultureelpolitieke standpunt van die Kaapse Kerk en sy predikante.

Dit is merkwaardig dat ds. Van der Hoff reeds in die vroeë jare van sy werksaamhede in die Oorvaalse so duidelik die strydpunte èn die beginsels wat daaraan ten grondslag gelê het, kon raaksien. 'n Noue assosiasie met sy mense en die aanvaarding van hulle strewe soos onder andere uiteengesit in die „politieke testament" van Kommandant-Generaal A. W. J. Pretorius het ds. Van der Hoff tot 'n welsprekende woordvoerder en vormgewer van die vryheids-

24) Aangehaal by S. P. Engelbrecht, Ds. Dirk van der Hoff, bls. 150. 
ideaal en patriotisme van die Republikeinse Afrikaner gemaak. Daarom is dit nodig dat sy bydrae op hierdie vlak behoorlik nagegaan en beskrywe moet word. ${ }^{30}$ )

Dit kan nou reeds gestel word dat ds. Dirk van der Hoff, deur sy lewe en werk, 'n positiewe bydrae lewer in die formulering èn uitbouing van die Republikeinse Afrikaner se christelik-nasionale lewens- en wêreldbeskouing. Dit was ds. Van der Hoff, as eerste in Transvaal, wat die noue verbondenheid van Kerk en volk voortdurend beklemtoon het en wat in die Voortrekkerkerk as 't ware die besorgdheid vir en die ontferming oor die Afrikanervolk ingebou het. Wat dit in die praktyk beteken het, word ons nie alleen geleer deur die besluite van die Algemene Kerkvergaderings van 1853 nie maar ook deur artikels 8, 9, 20, 23 en 24 van die Grondwet van die ou Republiek van 1858. Dáár word ook op amptelike vlak die noue verbondenheid van Kerk en volk beklemtoon en ook die kwaliteit van daardie verbondenheid omskrywe. Dáár blyk dit dat die geestelike identiteit van die Republikeinse Afrikaner Hervormd, dit wil sê Bybels-reformatories, bepaald sal wees.

Daarom is dit so eienaardig èn tiperend dat ' $n$ amptelike gelukwens en geskenk wat ds. Van der Hoff in 1878 , by sy 25 -jarige ampsjubileum van die destydse Engelse staatshoof ontvang het, deur dr. G. D. Scholtz uitgelê word as 'n duidelike bewys dat ds. Van der Hoff die Engelse anneksasie van die ou Republiek in 1877 volmondig aanvaar het ${ }^{31}$ ) en dat hy, net soos ds. Frans Lion Cachet en ds. J. P. Jooste eintlik Engelsgesind was en ' $n$ vyand van die Afrikaner se nasionale strewe!! ${ }^{23}$ )

Dán word vergeet dat ds. Van der Hoff, wat nié 'n vurige bewonderaar van President T. F. Burgers genoem kan word nie. reeds in Desember 1876 in De Volksstem teen die dreigende Engelse anneksasie gewaarsku het. Die verdeeldheid onder die Transvalers het hy as noodlottig vir die toekoms van die Republiek gesien en daarom die burgers opgeroep om die staatsgesag te ondersteun en te versterk want alleen op die manier sou die Republiek staande kon bly. Sy waarskuwing het egter op dowe ore geval en die anneksasie is sonder slag of stoot voltrek juis omdat die sentrale gesag van die Republiek nie meer op die steun van die volk kon staatmaak nie. Die swak leier het die volk verlam en verwar en dit was met bittere teleurstelling dat ds. Van der Hoff die anneksasie moes ervaar. Dit

30) F. A. van Jaarsveld, Die Ontwaking van die Afrikaanse Nasionale Bewussyn 1868-1881, Johannesburg 1957. Hier word ds. Van der Hoff se naam nie eers genoem nie!!

31) G. D. Scholtz, a.w., bls. 268.

32) S. P. Engelbrecht, Dr. G. D. Scholtz se geskiadenis.... artikel in Hervormde Teologiese Studies, Pretoria 1957, Jrg. 13, bls. 39. 
het hom egter nie belet om hom nog steeds met die vryheidsaak te vereenselwig nie hoewel hy fisies nie meer in staat was om deel te neem aan die volksvergaderings wat aan die vryheidsoorlog van 1880-1881 voorafgegaan het nie.

Met die inname van Potchefstroom deur die Boeremagte in 1880 het ds. Van der Hoff, onder die koeëls van die vegtende partye deur, hom na die kerkgebou gehaas om dit oop te sluit sodat die gebou as skuiling deur die Boere gebruik kon word. ${ }^{33}$ ) Wat hy nog kon doen, het hy gedoen en na die roemryke oorwinnings van die oorlog het ds. Van der Hoff nog 'n tweetal lofsange gedig wat opvallend is vanweë die duidelike christelik-nasionale gees wat daaruit spreek. ${ }^{34}$ ) Dit toon ook hoe die woordvoerders van die ou Republikeine die oorwinnings van Bronkhorstspruit, Ingogo en Majuba verstaan het in die lig van die Paardekraal-belofte van Desember 1880 en dit toon ook hulle christelik-bepaalde geskiedenisbeskouing. Basies sê ds. Van der Hoff hier presies dieselfde as wat President Kruger in 1891 in sy Paardekraalfeestoespraak sê. ${ }^{35}$ ) Daar behoort eintlik geen twyfel te bestaan dat ds. Van der Hoff in die midde van die nasionale lewe van die ou Republiek gestaan het en dat hy juis so en daar 'n bydrae gelewer het om die christeliknasionale lewens- en wêreldbeskouing van die Republikeinse Afrikaner te vorm en te omlyn. Net dáár het hy vir die Kaapse predikante en vir die handlangers van die Britse imperiale politiek in Suid-Afrika onaanvaarbaar geword. Daardie onaanvaarbaarheid word dan verder gevoer deur Spoelstra en diegene wat sy geskiedenisbeskouing met hom deel.

Op 9 Oktober 1881 is ds. Van der Hoff op 67-jarige ouderdom te Potchefstroom oorlede nadat hy reeds van die begin van sy sestigerjare met sy gesondheid gesukkel het. Vir meer as 28 jaar was hy, na die beste van sy vermoë, dienaar van die Goddelike Woord in die ou Republikeinse Hervormde Kerk. Op daardie aspek van sy lewenswerk is vandag nié die klem gelê nie aangesien met reg verwag kan word dat dit in hierdie geselskap nie onbekend sal wees nie.

As daar 'n voorlopige evaluering van ds. Van der Hoff se lewe en werk gemaak moet word, dan kan 'n mens waarskynlik die beste begin by ' $n$ waardering van ds. Van der Hoff wat deur prof. dr. A. N. Pelzer geskryf is. Hy het gestel: ${ }^{36}$ )

.33) S. P. Engelbrecht, a.w., bls. 39.

i4) S. P. Engelbrecht, Ds. Dirk van der Hoff, bls. 162-163.

$\therefore$ J) J. S. du Plessis, President Kruger aan die Woord, Bloemfontein s.j., bls. 95

36) A. N. Pelzer, a.w., bls. 200. 
.Ondanks die leemtes wat hom, soos enige aardse wese aangekleef het, moet ons erken dat hy beter as enige ander persoon voorbestem was om die geestelike bearbeiding van die hele uitgestrekte boere-gemeenskap, manalleen op sy breë skouers te neem. Slegs 'n persoon met sy werkvermoë kon die las van sy swaar taak oor ' $n$ hele aantal jare dra en al sou hy in die uitoefening van sy taak by meer as een geleentheid tekens van oorprikkelbaarheid geopenbaar het, dien dit alleen verder ter illustrasie van die besondere eise wat sy werk aan die psigiese weerstand van die kerklike en godsdienstige ampsdraer gestel het. In dieselfde mate moet sy neiging om invloed uit te oefen op ander terreine as die bloot kerklike, aanvaar word as ' $n$ aanduiding van die geweldige omvang van sy geestelike taak in die ongevormde Boere-gemeenskap. Ds. Van der Hoff het tydens sy ampsbediening nie alleen baanbrekerswerk nie maar ook beskawingswerk van onskatbare waarde verrig."

\section{Slotopmerkings.}

Uit die voorgaande word dit wel duidelik dat die figuur van ds. Dirk van der Hoff nié eenstemming beoordeel word nie. Sy groot verdienste word nie algemeen erken nie en tog lê dit, om te begin, dáárin dat hy die moed gehad om iets te doen waarvoor selfs die grote ds. Andrew Murray nie kans gesien het nie, naamlik om 'n beroep na die Voortrekkers in die Oorvaalse te aanvaar en om dáár sy lewe in diens van die Evangelieverkondiging en die Kerk wat hom geroep het, te slyt. Hoewel dit misken word, het ds. Van der Hoff deur hierdie daad juis gehelp om kontinuiteit aan die onafhanklike Voortrekkerkerk te gee. Daardeur het hy 'n bolwerk help bou waardeur die Voortrekkers en hulle nasate vir die grootste deel van die tweede helfte van die negentiende eeu beskerm is teen die Engelse invloede wat deur middel van die Kaapse Kerk en sy Engels-Amerikaanse metodistiese teologie na die Afrikaner deurgewerk het. Sodoende het ds. Van der Hoff ' $n$ groot bydrae gelewer, weliswaar saam met andere, in die behoud van die Bybels-reformatoriese teologie en in die op- en uitbou van die Afrikaner se christeliknasionale lewens- en wêreldbeskouing.

Ds. Van der Hoff het, soos geen ander predikant in ons geskiedenis nie, die moed èn die roepingsbewustheid gehad om hom as evangeliedienaar volledig te gee aan die Voortrekkergemeenskap wat hier in die Oorvaalse vir meer as sestien jaar alle reëlmatige kerklike voorregte ontbeer het. Deur volgehoue toewyding, deur groot persoonlike opofferinge en met 'n seldsame doelgerigtheid het hy hier in Transvaal gebou aan 'n kerklike gemeenskap wat die 
geestelike bolwerk van sy mense was, wat hulle in hulle pioniersarbeid en beskawingswerk nie alleen rigting gegee het nie maar ook versterk en geïnspireer het.

Inderdaad, ds. Van der Hoff het voortgebou op die werk van manne soos Erasmus Smit, die Amerikaanse sendeling Daniel Lindley, die eerste twee predikante van die onafhanklike Voortrekkerkerk èn op die sporadiese geestelike versorging van die besoekende Kaapse predikante. Maar hy was tog volkome bereid om vir meer as agt- en-twintig jaar die hitte van die dag en die koue van die nag sonder mumurering sáám met ..de oude emigranten“ te verduur en om saam met hulle te bou aan 'n nuwe, eie vaderland hier in die leë wêreld van die Oorvaalse. Só stewig was sy bouwerk dat die Ned. Hervormde Kerk, wat die logiese voortsetting van die onafhanklike Voortrekkerkerk is, die storms wat oor hom gegaan het, almal trotseer het. Laat ons net bedink wat dit ds. Van der Hoff aan moed, standvastigheid, deursettingsvermoë en leierskap moes gekos het om vanaf 1853 hier te werk. Ver van sy vaderland, wat hy nooit weer gesien het nie; ver verwyder van die gerief en gemak van die beskawing; sonder enige noemenswaardige traktement vir die grootste deel van sy lewe alhier; meestal op reis met 'n ossewa dwarsoor die hele Transvaal en later deur Wes-Transvaal het hy nogtans nooit laat slaplê nie of self lam geword nie. As dienaar van die Goddelike Woord en as dienaar van die Kerk het hy ook nog 'n oop oog èn hart gehad vir die nasionale strewe van sy volk. Met Gods Woord het hy op alle lewensterreine sy mense in hulle doen en late begelei, het hy vermaan, aangespoor, moed ingepraat, getroos, geïnspireer en leiding gegee en geneem.

Onder dit alles moes hy homself voortdurend verweer teen aanvalle wat op sy persoon, sy werk en die Kerk gemaak is. Juis omdat hy, net soos sy Kerk en volk, in die pad gestaan het van die Engelse imperialistiese magsstrewe van sy tyd, is hy dikwels aangeval en verdag gemaak. Daarteen het hy homself op ' $n$ baie bekwame wyse verweer en terselfdertyd ook daardie geestelike waardes beklemtoon wat Kerk en volk in staat gestel het om sy koers te hou.

Hoewel die wetenskaplike, verantwoorde biografie van ds. Van der Hoff nog nie geskryf is nie, is dit wel duidelik dat hierdie evangeliedienaar, met die foute en tekortkominge wat hy gehad het, één van die groot leiersfigure van Kerk en volk in die vroeë jare van die Voortrekkergemeenskap in Transvaal was. Merkwaardig genoeg het hy daarvoor baie meer verguising as waardering tydens en na sy lewe ontvang. Die bewondering word skynbaar gebêre vir 'n figuur soos sy tydgenoot Livingstone wat, onder die dekmantel van sendeling te wees, allerlei vir homself lonende en interessante jagtogte 
en ontdekkingsreise gemaak het, wapens gesmokkel het om so die Nie-blanke teen die Afrikaner te bewapen en verder die pad oopgemaak het vir die Engelse imperialistiese magsstrewe in Afrika. Wat Livingstone egter van blywende waarde ten opsigte van die kerstening van Nie-blanke Afrika gedoen het, moet nog ontdek word.

As mens egter so, om weer terug te kom, kyk na die figuur van ds. Van der Hoff dan is dit te verstane dat die Teologiese Studentevereniging in 1924 die naam Van der Hoff aan hulle vereniging gegee het.

Daardie naam impliseer in 1974, net soos in 1924, 'n toewyding en 'n lewenslange volgehoue werkywer ten behoewe van die evangelie van Jesus Christus.

Dit impliseer egter óók 'n noue verbondenheid aan en 'n verantwoordelikheid vir die Afrikanervolk aan wie in die eerste plek die evangelie verkondig moet word en op alle lewensterreine toegepas moet word.

Dit impliseer ' $n$ assosiasie met die Afrikanervolk en 'n verantwoordelikheid vir die ideale en strewe van hierdie volk wat al so baie geoffer het ter wille van sy vryheid, sy blanke selfbeskikkingsreg èn sy reg om sy toekoms tegemoet te lewe in die verlengstuk van sy verlede.

Anders gestel: omdat die christelik-nasionale strewe bepalend is vir die toonaard van die Kerk se teologiese opleiding ${ }^{37}$ ) is dit so vanselfsprekend dat die Teologiese Studentevereniging ook in 1974 met trots die naam Van der Hoff dra. Juis deur daardie naam te dra in die gees van die man wat ter wille van die evangelie en die welwese van die republikeinse Afrikaner alles feil gehad het, maak ons Teologiese Vereniging die woorde van ds. N. J. van Warmelo waar wat gesê het: „Zijne nagedachtenis zal in eere blijven, zoo lang de Transvaal bestaat."

3i) B. J. Engelbrecht, Christelik-nasionaal as toonaard van die Teologiese Vereniging Van der Hoff en die Opleiding van ons Kerk, artikel in Die Hervormer, Maart 1974, bls. $10 \mathrm{vg}$. 